УДК 94 (470+571):930

КУЗНЕЦОВ Олег Викторович - кандидат исторических наук, доцент; заведующий кафедрой отечественной и всеобщей истории, археологии Волгоградского государственного университета (400062, Россия, г. Волгоград, Университетский пр-кm, 100; oleg.kuznetsov@volsu.ru)

ЛОТАРЕВ Константин Анатольевич - кандидат политических наук, доцент кафедры международных отношений, политологии и регионоведения Волгоградского государственного университета (400062, Россия, г. Волгоград, Университетский пр-кт, 100; lotarev@volsu.ru)

\title{
ДВЕ «ПРАВДЫ»: ЯРОСЛАВ МУДРЫЙ И ПАВЕЛ ПЕСТЕЛЬ: К ВОПРОСУ ПОИСКА И УТВЕРЖДЕНИЯ ПОЛИТИКО-ИСТОРИЧЕСКИХ СМЫСЛОВ «ПРАВДЫ» И «ЗАКОНА» В ПОЛИТИЧЕСКОЙ ИСТОРИИ РОССИИ Часть 2
}

\begin{abstract}
Аннотация. Статья продолжает исследование, опубликованное в № 2 журнала за 2021 г. Авторы акцентируют внимание на одной из ключевых проблем в политической истории России - проблеме поиска и утверждения в государственной и общественной жизни приемлемых, органичных, естественных норм, правил и ценностей, соответствующих нравственному и ментальному состоянию народа. Эта проблема многоуровневая и многоаспектная, во многом решаемая, но в идеале неразрешимая по той причине, что в течение веков на долю народа и власти выпадает множество непредсказуемых и трудно структурируемых событий, влияющих на исторический и политический процесс. Политические, правовые и ценностные парадигмы меняются под воздействием разнообразных и противоречивых обстоятельств. В качестве основных источников привлекаются: «Русская Правда» Ярослава Мудрого, «Русская Правда» П.И. Пестеля, «Слово о Законе и Благодати» митрополита Илариона.
\end{abstract}

Ключевые слова: Закон, Правда, Справедливость, традиция, конституционный проект, законы государственные, закон Божественный, монархия, республика, власть, народ, государство

$\mathrm{O}$ бращение к историческим традициям не ограничилось только названием. Своеобразный исторический диалог с древней и средневековой Русью П.И. Пестель продолжил и дальше. Столицу новой России он предлагал перенести в Нижний Новгород, переименовав его во Владимир «в память великого мужа, введшего в Россию христианский закон». Упоминание о крещении Руси здесь принципиально. По П.И. Пестелю, все государственные законы должны восходить к Законам Божеским, быть с ними в полном «согласии», ибо «Бог творец Вселенной есть и творец законов природы, нужд естественных»1.

Выбор новой столицы автор «Русской Правды» объяснял среди других причин тем, что отсюда началось «освобождение России от ига иноплеменного чрез Минина и Пожарского», и «все воспоминания о древности Нижегородской дышат свободой и прямой любовью к Отечеству, а не к тиранам его» ${ }^{2}$. И в этом объяснении П.И. Пестеля заключен очень важный для него сплав идей свободы и патриотизма, подлинным носителем которого он видел не самодержавие, а русский народ, спасший Россию от неминуемой, казалось, гибели.

\footnotetext{
1 Восстание декабристов: документы. Т. VII: «Русская Правда» П.И. Пестеля и сочинения, ей предшествующие (под ред. М.В. Нечкиной). М.: Госполитиздат. 1958. С. 115.

2 Там же. С. 129.
} 
Названия основных органов власти также восходят у П.И. Пестеля к традиционным русским институтам. Высшей законодательной властью должно было стать Народное вече. В своих наиболее развитых формах оно, как мы помним, существовало в Великом Новгороде, откуда и пришла «Правда Ярослава». Да и сама республиканская форма правления, сторонником которой был П.И. Пестель, также напоминает нам об этом городе. Объясняя на допросе истоки своих республиканских воззрений, П.И. Пестель указывал среди прочего и на русские исторические традиции: «История Великого Новгорода меня также утверждала в республиканском образе мыслей» [Павлов-Сильванский 1907: 29]. Исполнительная власть вверялась Державной думе. Со времен Киевской Руси так назывался совещательный орган при князе. Наконец, главным «блюстительным» (т.е. контролирующим) учреждением должен был стать Верховный собор. Традиция их созыва также идет из Древней Руси. Так, в 1211 г. Всеволод Большое Гнездо созывает Собор во Владимире для решения вопроса о наследовании великокняжеского стола.

На первый взгляд, «диалог» П.И. Пестеля с русской историей касался внешней, формальной стороны - был номинальным в буквальном смысле: заимствовались названия. В действительности, как нам представляется, этот «диалог» затронул и само содержание пестелевского проекта. И последнее слово осталось за русской историей. Целесообразно пояснить эту мысль.

Вспомним еще раз о заочной полемике Н.М. Карамзина и М.М. Сперанского. В этом споре П.И. Пестель в соответствии со своими политическими убеждениями был, безусловно, на стороне М.М. Сперанского. Автор «Русской Правды», несомненно, стремился утвердить Свободу через Закон, оградить ее Законом. О своем неверии в Правду властей он прямо говорил в вводной части проекта: «Недостаток в таковой Грамоте (то есть Законе. - O.K., K.Л.) ввергнул многие государства в ужаснейшие бедствия и междоусобия, потому что в оных правительство действовать всегда могло по своему произволу, по личным страстям и частным видам, не имея перед собою ясного и полного наставления, коим бы обязано было руководствоваться, и что народ между тем никогда не знал, что для него предпринимают, никогда не видел ясным образом, к какой цели стремятся действия правительства и, волнуемый разными страхами, а потом и разными страстями, часто предпринимал беспокойные действия и наконец междоусобия производил. Русская Правда отвращает своим существованием все сие зло и приводит государственное преобразование в положительные ход и действие тем, что все определяет и на все предметы коренные правила издает» 1 .

Более того, у П.И. Пестеля мы видим некий культ Закона, его своеобразную абсолютизацию: «самые действительные наставники народов суть Законы государственные: они образуют и, так сказать, воспитывают народы, и по ним нравы, обычаи, понятия вид свой и деятельность свою получают, от них исходят направление умов и волей; и потому утвердительно сказать можно, что политические и гражданские Законы соделывают народы таковыми, каковыми они суть» ${ }^{2}$.

Строго говоря, идея примата Закона над Традицией, если угодно, над Правдой, по своей сути - либеральная. Но, как ни парадоксально, первую серьезную попытку реализовать эту идею на российской почве предпринял Петр I, хотя его идеал и отчасти детище - это регулярное полицейское государство - государство централизованное, с естественным правом вмешательства

\footnotetext{
1 Там же. С. 119.

2 Там же. С. 138.
} 
в политическую, религиозную, социально-экономическую и частную сферу жизни подданных, что, вне всякого сомнения, бесконечно далеко от либерализма.

Тем не менее реформы Петра I целесообразно интерпретировать как движение от общества традиционного к обществу, переходящему постепенно к рациональным основам. Фактически было положено начало созиданию основ российского либерализма, но на фундаменте абсолютистского государства. Последующая политическая история России покажет, что русский либерализм развивался вплоть до конца XIX в. как либерализм этатистский.

Один из основоположников русского консерватизма князь М.М. Щербатов считал Петра I виновным в начале «повреждения нравов в России», поскольку дворянству постепенно было привито «сластолюбие». Иначе это можно определить как форму утилитаризма. Утилитаризм основывается на осознании связи роста благ и личных усилий по их добыванию, и этим готовит психологическую основу и почву для либерализма, выступая его предшественником [Китаев 1994: 132].

Возможно, отнюдь не случайно из «гнезда Петрова» «выпорхнул» В.Н. Татищев, выступивший уже в 1730 г., во время так называемого заговора верховников, с идеей ограничения самодержавия. Либеральный историк А.А. Кизеветтер назвал В.Н. Татищева «первым теоретиком русского либерализма» [Кизеветтер 1912: 63].

В современной литературе неоднократно отмечался либеральный характер идеологии декабризма [Китаев 2008: 332, 345, 352].

При этом очевидным является тот факт, что для укоренения и развития либеральных идей в России не было соответствующих политических и социальноэкономических условий. Книжный во многом либерализм П.И. Пестеля ложился, таким образом, на весьма жесткую абсолютистскую подушку, и это сочетание сказалось, что называется, на конечном результате. Идеи автора «Русской Правды» действительно выглядят достаточно либеральными и демократичными. Но за его рассуждениями о гражданском обществе, выборном начале, необходимости разделения властей, правах и свободах и тому подобном просматриваются политические конструкции и явления отнюдь не либерального и не демократического толка.

Уже в самом названии проекта П.И. Пестеля говорится о Временном верховном правлении, для которого «Русская Правда» и представляет собственно «завет» и «верный наказ». Под этим Верховным правлением подразумевалось не что иное, как революционная диктатура сроком не менее 10 лет. В течение этого времени и предполагалось реализовать основные положения «Русской Правды». Не просто «усовершенствовать государственное устройство России», как уверял автор, а радикально изменить ее административно-территориальное устройство, политический строй, социально-экономические отношения и национальный состав, церковную жизнь.

В «Русской Правде» бросается в глаза предельная регламентация всех сфер жизни, что невольно вызывает ассоциации с петровским регулярным полицейским государством. При этом в своем стремлении к детальной регламентации П.И. Пестель превзошел Петра Великого. Достаточно одного примера: священников предполагалось превратить в чиновников (духовенство - «отрасль чиноначальства», «чиновные особы»).

Власть, по П.И. Пестелю, обязана «избирать лучшие средства для доставления в государстве благоденствия всем и каждому», а потому вправе требовать от народа повиновения. Это поразительно близко к идее патернализма, которая является неотъемлемым идеологическим атрибутом полицейского госу- 
дарства. Патернализм был, как известно, одной из основных идейных установок Петра Великого [Анисимов 1989: 52-63].

Заявление П.И. Пестеля, что народ вправе требовать от правительства непременного стремления к общественному и частному благоденствию, мало что меняет: решать на практике, в чем заключается народное благоденствие, какие средства избирать для его утверждения, будут уж точно не «повинующиеся», а «повелевающие», если использовать терминологию самого автора конституционного проекта.

Весьма императивно звучит, как дополнение к сказанному, и требование неукоснительно следовать положениям «Русской Правды», и фактическое предписание народу не только не сопротивляться диктатуре, но и всячески ей способствовать, ибо действовать она будет во благо народное: «Временное верховное правление обязано новый государственный порядок, Русскою Правдою определенный, постепенными мероприятиями ввести и устроить, а народ обязан сему введению не только не противиться, но, напротив того, Временному верховному правлению усердно всеми силами содействовать и неуместным нетерпением не вредить преуспеванию народного возрождения и государственного преобразования» 1 .

Одну из важнейших мыслей, лежавших в основе политических построений «Русской Правды», П.И. Пестель выразил следующим образом: «...правительство есть принадлежность народа, и оно учреждено для блага народного, а не народ существует для блага правительства» 2 .

Эта цитата заставляет нас вспомнить еще об одной принципиальной идейной установке Петра I - идее служения.

В концепции средневекового самодержавия ключевой была идея государства-вотчины, что, впрочем, не удивительно. Русское централизованное (или Единое российское) государство сформировалось на основе великокняжеской вотчины: Великого княжества Московского. И в этом отношении концепция основных теоретиков государственной школы К.Д. Кавелина и Б.Н. Чичерина (род - вотчина - государство) не так уж далека от реальности. На основе дворцово-вотчинной системы складывались общерусские формы управления: в одних и тех же органах поначалу были сосредоточены и функции государственного аппарата, и функции хозяйственно-административного аппарата великокняжеского домена. Великие князья московские и всея Руси, потом и первые русские цари видели государство как свою вотчину, в которой их власть безраздельна [Скрынников 1997: 206].

Историки В.Б. Кобрин и А.Л. Юрганов определили характер этой власти как «деспотическое самодержавие» [Кобрин, Юрганов 1991].

Петр I внес в идею и осуществление самодержавия идею служения. Представляется емким суждение Е.В. Анисимова, основанное на глубоком проникновении в источники: «идея служения России, как он (Петр I. - O.K., K.Л.) это понимал, стала главным стержнем его жизни, наполняла для него высшим смыслом все его действия и поступки, даже самые неблаговидные и сомнительные с точки зрения тогдашней морали» [Анисимов 1989: 23].

Вероятно, трагедия российского самодержавия заключалась не только в том, что в XIX в. оно промедлило с решительным проведением реформ и особенно с реформой политической. П.Б. Струве предельно обострил саму постановку вопроса: «Историческое несчастье России, к которому восходит трагическая катастрофа 1917 г., обусловлено <... тем, что политическая реформа страшно

\footnotetext{
1 Там же. С. 119-120.

2 Там же. С. 116.
} 
запоздала в России. В интересах здорового национально-культурного развития России она должна была бы произойти не позже начала XIX века. Тогда задержанное освобождение крестьян (личное) быстро за ней последовало бы, и все развитие политических и социальных отношений протекало бы нормальнее» [Струве 1990: 241].

Последние самодержцы Российской империи утратили идею служения. Наследовав престол, Николай II заявил: «Да поможет мне Господь служить горячо любимой Родине так же, как служил ей мой покойный отец» [Боханов 1994: 314].

Но эти слова о служении - не более чем фигура речи. Понимание Николаем II своего предназначения даны им в красноречивом ответе о роде занятий в ходе первой общероссийской переписи населения 1897 г.: «хозяин земли русской» [Боханов 1994: 114].

Ментальная ли это опора на средневековую концепцию государства-вотчины? Вопрос едва ли разрешимый. Но можно утверждать, что российская монархия рубежа XIX-XX вв. была более укоренена в прошлом и в нем искала свою политико-идеологическую опору. В итоге усугублялся отрыв от реальности, и вследствие этого самодержавие пришло к своему краху.

Возможно, П.И. Пестель не видел идеи служения уже у современного ему монарха. Как бы то ни было, в русских условиях, с учетом исторических традиций эта идея изначально, так сказать, монархическая; первоначально она должна быть персонифицирована, правитель сам должен ее исповедовать, подавать пример служения и требовать того же от подданных.

П.И. Пестель - убежденный сторонник централизованного государства и, соответственно, противник федерализации: «объявляется Российское государство 〈...> единым и неразделимым, отвергающим притом совершенно всякое федеративное образование, устройство и существование государства» 1 .

Унитарное устройство в представлениях П.И. Пестеля могло предотвратить многие бедствия, выпавшие на долю удельной системы Древней Руси, которая была в определенном смысле государством федеративного устройства ${ }^{2}$. Проводя параллели между федерализмом и удельной системой с ее междоусобицами, П.И. Пестель, сам, видимо, того не желая, поддерживал господствовавшую в XVIII в. историческую концепцию, впоследствии названную дворянско-монархической. Суть концепции сводится к тому, что изначально на Руси существовала монархия в форме сильной княжеской власти. Ее ослабление привело к распаду Руси и утверждению раздробленности. Восстановление единства государства было связано с возрождением сильной великокняжеской власти (монархии). Позднее эта концепция найдет отражение в теории официальной народности. Казалось бы, П.И. Пестель должен быть бесконечно далек от ее автора С.С. Уварова. Но их объединяет тяга к сильной верховной власти. И здесь вполне логично признание, сделанное П.И. Пестелем на следствии, о пересмотре своих республиканских воззрений: «Объявив таким образом в самом откровенном и признательном изложении весь ход либеральных и вольнодумных моих мыслей, справедливым будет прибавить к сему, что в течение всего 1825 года стал сей образ мыслей во мне уже ослабевать, и я предметы начал видеть несколько иначе, но поздно уже было совершить благополучно обратный путь. Русская Правда не писалась уже так ловко, как прежде» [Павлов-Сильванский 1907: 29-30]. Можно говорить о том, что П.И. Пестель

\footnotetext{
1 Там же. С. 127.

2 Там же.
} 
пытался этим признанием смягчить свою вину, но оно вполне укладывается в логику его политических размышлений и построений.

Унитарное государство П.И. Пестеля мыслилось как мононациональное: «Все племена должны слиты быть в один народ. ...при всех мероприятиях Временного верховного правления в отношении к различным народам и племенам, Россию населяющим, беспрестанно должно непременную цель иметь в виду, чтобы составить из них всех только один народ и все различные оттенки в одну общую массу слить, так чтобы обитатели целого пространства Российского государства все были русские» ${ }^{1}$. В отношении каждого народа, населяющего государство, П.И. Пестель предлагал меры, в результате которых «все различные племена, в России обретающиеся, к общей пользе совершенно обрусеют и тем содействовать будут к возведению России на высшую степень благоденствия, величия и могущества» ${ }^{2}$. Национальный вопрос обретет актуальность в русской общественной мысли только во второй половине XIX в. Развитие буржуазных отношений стимулирует национальное самосознание отдельных народов, населявших преимущественно окраины империи - Привислинский край, Литву, Остзейские губернии, Финляндию, - усилит их тягу к самостоятельности и отделению от России. Польское восстание 1863 г. обнаружит все промахи национальной политики, точнее, ее отсутствие как таковой [Дякин 1995]. В этих условиях громко прозвучат призывы о необходимости проведения национальной политики, что предполагало в первую очередь обрусение названных окраин. Но исходить эти призывы будут прежде всего из консервативного лагеря [Кузнецов 2000]. Таким образом, в этом вопросе П.И. Пестель предвосхитил, подчеркнем, консервативных публицистов.

Спор о том, что важнее - Закон или Правда, для России имел и имеет принципиальное значение. Отрицание необходимости жить по Закону, необходимости законодательного закрепления свобод политических, экономических, гражданских может при определенных условиях привести к деспотизму. Но выскажем крамольную, видимо, для любого приверженца либеральных идей мысль: абсолютизация свободы, стремление к непременному ее законодательному оформлению также легко при определенных условиях может привести к диктатуре. К либеральной диктатуре, при которой тем, кто противится установлению свободы, уготовано, как у П.И. Пестеля, место на эшафоте. Так, дворян, которые осмелились бы выступить против лишения их сословных привилегий и отмены крепостного права («словом или делом вздумал сему действию противиться или оное осуждать»), П.И. Пестель называл извергами и недостойными сынами Отечества и настаивал на применении к ним самых суровых мер: «...всякого такового злодея безызъятно немедленно взять под стражу и подвергнуть его строжайшему наказанию, яко врага отечества и изменника против первоначального коренного права гражданского» ${ }^{3}$. Показательно, что дворянам отказывалось в праве даже поднимать свой голос в защиту собственных прав.

«Русская Правда» П.И. Пестеля в ее первоначально замышлявшемся варианте должна была скорее всего воплотить идеалы, почерпнутые автором из европейских политических учений. Идеалы во многом либеральные. В итоге получилось, осмелимся утверждать, даже чуть больше, чем Русская Правда.

В метафизическом смысле история России - это история борьбы за утверждение Русской Правды. Периодически возникают разговоры о необходимо-

\footnotetext{
1 Там же. С. 149.

2 Там же. С. 150.

3 Там же. С. 157.
} 
сти поиска национальной идеи. А не дана ли она всей нашей историей? Наша национальная идея не заключена ли в Русской Правде? Россия - территориально обширное, богатое и могущественное многонациональное государство. Исторически под воздействием внешних и внутренних условий в России сформировалась и осушествлялась сильная централизованная власть. Народы, входящие в состав России, полностью сохраняли свою социальную структуру и внутренний мир, что не мешало им утверждаться в различной деятельности. Политическая история свидетельствует об отсутствии у России агрессивных, захватнических планов. Политика России вплоть до 1917 г. отличалась толерантностью и признанием сложившегося политического и социально-экономического быта народов, вошедших в ее состав. Показательно, что она не навязывает никому свою Правду, но одновременно отстаивает свои национальные интересы.

Россия изначально складывалась как многонациональное государство. Народы, для которых Россия была или стала настоящей родиной, не нуждались в обрусении. Сохраняя свою национальную самобытность, они в то же время оставались органичной и потому неотделимой частью большой многонациональной страны, сильной единством народов.

Русская Правда выкристаллизовывалась под влиянием разных факторов: географического положения страны и связанных с этим ее природно-климатических условий, особенностей политической, социальной, религиозной организации, экономической деятельности и исторического развития, взаимоотношений с соседними государствами и народами. Русская Правда стала неотъемлемой частью русской истории и русской жизни, но в то же время чем-то самостоятельным, не зависящим от политических режимов, конкретных исторических лиц. Даже тогда, когда Россия, казалось, отступала от своей Правды, она всегда пробивала себе дорогу, всегда находились силы, несшие эту Правду.

Русская Правда Ярослава Мудрого и «Русская Правда» П.И. Пестеля - это не начальная и конечная точки в истории борьбы за ее утверждение. Это вехи, свидетельствующие, что главные ориентиры не потеряны: это представления о себе и мире, вере и безверии, правде и лжи, добре и зле, справедливости и несправедливости, законе и беззаконии, праве и бесправии, чести и бесчестии, свободе и несвободе, верности долгу и предательстве национальных и государственных интересов, преступлении и возмездии.

Исследуемая проблема имеет интегративный характер: исторический, политический, ментальный, культурно-образовательный и культурно-правовой. Следовательно, она может быть предметом изучения и исторической, и политической, и правовой науки. Проведенное исследование позволяет констатировать и утверждать следующие выводы о прошлом и смысловые конструкты, необходимые для утверждения и реализации в будущем. В историческом контексте две Правды - Ярослава Мудрого и П.И. Пестеля - свидетельствуют о стремлении органически соединить в одно целое Правду и Закон. Необходимо помнить, что в случае с Русской Правдой великого князя Ярослава Мудрого мы видим объективно и органично выраженное стремление власти разработать такое законодательство, в котором бы естественным образом право не противоречило сложившимся в социуме представлениям о справедливости и мере. В юридической терминологии - это обычное право, т.е. право, основанное на обычае. Справедливость и мера заключаются в феномене Правды. Правда в этом аспекте представляется как более сложное ментальное и социальное отражение реальности, поскольку при неизбежном появлении в общественной жизни разного рода конфликтов, нарушений и преступлений, торжество закона далеко не всегда удовлетворяет ожиданиям потерпевшей стороны. На 
Руси в течение веков в судебной практике на основе обычаев утвердилась как основная норма возмещение за обиду (вира в натуральном или денежном виде). А право свободного человека на кровную месть олицетворяло самое адекватное воздаяние и меру. С течением веков государственная власть станет единственным субъектом влияния в правовых отношениях в лице судебной системы. Но непреодолимое стремление русских людей к Правде и Справедливости говорит само за себя. Несовершенство законов (нередко и изменяемых, и переписываемых по воле власти или законников) - источник этого стремления.

В случае с «Правдой» П.И. Пестеля также следует помнить, что этот законодательный проект - творчество высокообразованного представителя дворянского сословия. В силу этого «Правда» П.И. Пестеля - труд во многом субъективный, с несомненными чертами радикального эклектического волюнтаризма, не без внутренних противоречий, но также отмеченный глубоко искренним стремлением закрепить в законодательстве основополагающие принципы и положения, способствующие крепости и стабильности государственного и социального устроения. Само обращение дворянина П.И. Пестеля - человека героического, человека чести - к слову «Правда» говорит о многом, и в частности о не пресекающемся в веках российской истории стремлении народа к Правде. Правде, отраженной в законодательстве.

В прогностическом и политическом аспектах в настоящее время исследуемая проблема не теряет своего теоретического и практического содержания. С 1990-х гг. и по настоящее время Россия переживает очередной, вероятно, затянувшийся излом в своей политической, социально-экономической, культурно-правовой истории. Проблемы в основных сферах управления государством и обществом в условиях информационного века не только более заметны в своей остроте, но и более разрушительны в своих потенциальных угрозах.

Своекорыстие, волюнтаризм, некомпетентность, коррумпированность органов власти и суда Россия переживала не однажды. Демократию не строят. Демократия возникает там и тогда, когда для нее есть основы и ресурсы, создаваемые на протяжении долгого исторического времени: самодостаточный средний класс; сильная производительная экономика; высокая образованность и компетентность избранных на определенный срок представителей власти; общество институционально организованное и активное; приверженность незыблемым принципам законности и справедливости; конкурентность сформированных элит в лице реальных парламентских и оппозиционных партий. Без этого системной, а потому и прочной демократии нет. Народ как источник власти - принцип, утвержденный Конституцией России. В современных условиях информационного общества власть уже не имеет монополию на информацию, знание и влияние. По этой причине только осознание необходимости сотрудничества общественных и государственных институтов станет началом и реального практического сотрудничества - неизменного в реализации основных общественных интересов. Тогда Закон и Правда станут источником и основой друг друга.

\section{Список литературы}

Анисимов Е.В. 1989. Время Петровских реформ. Л.: Лениздат. 495 с.

Боханов А.Н. 1994. Николай II. - Российские самодержцы. М.: Международные отношения.

Дякин В.С. 1995. Национальный вопрос во внутренней политике царизма (XIX в.). - Вопросы истории. № 9. С. 130-142.

Кизеветтер А.А. 1912. Из истории русского либерализма. Иван Петрович Пнин. 1773-1805 гг. - Исторические очерки. М.: ОКТО. С. 57-90. 
Китаев В.А. 1994. У истоков русского консерватизма (М.М. Щербатов и Н.М. Карамзин). - Материалы ХІ научной конференции профессорско-преподавательского состава. 18-22 апреля 1994 г. Волгоград: Изд-во ВолГУ. С. 131-137.

Китаев В.А. 2008. ХІХ век: пути русской мысли: научные труды. Нижний Новгород: Изд-во Нижегородского университета. 355 с.

Кобрин В.Б., Юрганов А.Л. 1991. Становление деспотического самодержавия в средневековой Руси. (К постановке проблемы). - История СССР. № 4. С. 54-64.

Кузнецов О.В. 2000. Национальный вопрос в публицистике М.Н. Каткова (1860-е годы). - Вестник Волгоградского государственного университета. Сер. 4. История. Философия. Вып. 5. С. 40-49.

Павлов-Сильванский Н.П. 1907. Декабрист Пестель перед Верховным уголовным судом. Ростов н/Д: Изд. А. Сурат; Тип. «Донская речь». 186 с.

Скрынников Р.Г. 1997. История Российская. IX-ХVII вв. М.: Весь Мир. 496 с.

Струве П.Б. 1990. Исторический смысл русской революции и национальные задачи. - Из глубины: сборник статей о русской революции. М.: Изд-во МГУ. 298 c.

KUZNETSOV Oleg Viktorovich, Cand.Sci. (Hist.), Associate Professor; Head of the Chair of Russian and World History, Archaeology, Volgograd State University (100 Universitetsky Ave, Volgograd, Russia, 400062; oleg.kuznetsov@volsu.ru) LOTAREV Konstantin Anatol'evich, Cand.Sci. (Pol.Sci.), Associate Professor of the Chair of International Relations, Political Science and Regional Studies (100 Universitetskiy Ave, Volgograd, Russia, 400062; lotarev@volsu.ru)

\title{
TWO «TRUTHS»: YAROSLAV THE WISE AND PAVEL PESTEL': ON THE ISSUE OF SEARCHING FOR AND ASSERTING THE POLITICAL AND HISTORICAL MEANINGS OF «TRUTH» AND «LAW» IN THE POLITICAL HISTORY OF RUSSIA
}

\section{Part 2}

\begin{abstract}
The article continues the paper printed in Vlast', №2, 2021. It focuses on one of the key problems in the political history of Russia - the problem of finding and establishing acceptable, organic, natural norms, rules and values in state and public life that correspond with the moral and mental state of the people. This is a multi-level and multi-faceted problem, largely solvable, but ideally unsolvable for the reason that over the centuries, the people and the authorities have numerous unpredictable and difficultly structured events affecting the historical and political process. Political, legal, and value paradigms change under the influence of diverse and contradictory circumstances.

The main sources are "Russian Truth» by Yaroslav the Wise, «Russian Truth» by P.I. Pestel', "The Word about Law and Grace» by Metropolitan Hilarion.

Keywords: Law, Truth, Justice, tradition, constitutional project, state laws, Divine law, monarchy, republic, power, people, state
\end{abstract}

